Chapter 6

\title{
Approach to Subclinical Hypothyroidism in Children
}

\author{
Yardena Tenenbaum-Rakover \\ Additional information is available at the end of the chapter \\ http://dx.doi.org/10.5772/55134
}

\section{Introduction}

\subsection{Definition of $\mathrm{SCH}$}

$\mathrm{SCH}$ is defined when serum TSH concentration is above the statistically upper limit of the reference range while serum free $\mathrm{T}_{4}\left(\mathrm{FT}_{4}\right)$ concentration is within its reference range (Biondi \& Cooper, 2008; Surks et al., 2005). Other names for SCH include compensated, early, latent, mild, minimally symptomatic, preclinical hypothyroidism and euthyroid hyperthyrotropinemia (Chu \& Crapo, 2001). It suggests a compensated early state of primary thyroid failure wherby an increased level of TSH is required to maintain notmal levels of thyroid hormones. The reference TSH levels in a normal population aged 12 and older (excluding individuals with medications or diseases that might influence thyroid function) were assessed at 0.45 to 4.12 $\mathrm{mIU} / \mathrm{l}\left(2.5^{\text {th }}-97.5^{\text {th }}\right.$ percentile) (Hollowell et al., 2002). Although there were age, gender, and ethnic group differences, they were small and it was therefore not considered necessary to adjust the reference for these parameters. Additional studies assessing the normal TSH reference in children have shown broad differences between adult and children that were dependent on the patient's age (Elmlinger et al., 2001; Hübner et al., 2002; Kapelari et al., 2008 ; Soldin et al., 2009; Strich et al., 2012; Zurakowski et al., 1999), indicating that the definition of SCH is age-dependent. A panel of experts divided patients with $\mathrm{SCH}$ into two groups: patients with mildly increased serum TSH levels $(4.5-10 \mathrm{mIU} / \mathrm{l})$ and patients with more severely increased serum TSH levels (>10 mIU/l) (Surks et al., 2004).

\section{Prevalence of SCH}

The prevalence of $\mathrm{SCH}$ is about $4 \%$ to $10 \%$ in the adult population (Biondi \& Cooper, 2008; Hollowell et al., 2002; Surks et al., 2004), with a higher prevalence in women and the elderly. 
The prevalence of congenital hypothyroidism $(\mathrm{CH})$ has increased in the last two decades from 1 in 4000 births (Grüters et al., 1993) to as high as 1 in 2000 births in the Hispanic population in the United States (Harris \& Pass, 2007). Explanations for the increase in prevalence of $\mathrm{CH}$ in the United States include lower TSH cut-off levels, increasing numbers of preterm or very low weight babies who can be affected by a transient rise in TSH levels and reflect more benign or transient cases (Grüters \& Krude, 2011) and higher numbers of neonates with Hispanic background in the tested population. The precise incidence of $\mathrm{SCH}$ in children is not well defined; however, a prevalence of about 1 in 8260 births was found in Europe for transient $\mathrm{CH}$ and SCH (Klett \& Schönberg, 1981).

\section{Etiology of SCH}

The different causes of SCH in children are summarized in Table 1. The most common cause in children, as well as in adults, is AITD. In the newborn, hyperthyrotropinemia can reflect a physiological condition, as well as maternal AITD and perinatal exposure to iodine. Loss-offunction mutations of genes that are involved in thyroid development and thyroid hormone synthesis may also present as euthyroid hyperthyrotropinemias at birth or later on in life. Additional etiologies are acquired thyroid infiltration diseases, thyroid injury, and secondary effects of medication that influences thyroid hormone synthesis or clearance of thyroid hormones. Mild hyperthyrotropinemia may be a consequence of obesity. Laboratory interference in the assay process is not a rare cause for elevated TSH. Many of these causes result in overt hypothyroidism with time, or even at presentation.

\begin{tabular}{|c|c|}
\hline AITD & $\begin{array}{l}\text { Risk factors: family history of AITD-associated } \\
\text { autoimmune disorders (diabetes mellitus type 1, celiac } \\
\text { disease, pernicious anemia, viteligo, atrophic gastritis, } \\
\text { etc.) as part of autoimmune polyglandular syndrome type } \\
1 \& 2 \text {. In Down syndrome and Turner's syndrome }\end{array}$ \\
\hline Congenital hyperthyrotropinemia & $\begin{array}{l}\text { lodine exposure or endemic iodine deficiency, maternal } \\
\text { AITD, maternal drug treatment like propylthiouraciland } \\
\text { metimazole }\end{array}$ \\
\hline \multicolumn{2}{|l|}{$\begin{array}{l}\text { Persistent TSH after subacute thyroiditis or painless } \\
\text { thyroiditis }\end{array}$} \\
\hline Thyroid injury & $\begin{array}{l}\text { Partial thyroidectomy, radioactive iodine therapy, } \\
\text { external radiotherapy of head and neck, chemotherapy }\end{array}$ \\
\hline Drugs & $\begin{array}{l}\text { lodine and iodine-containing medications (amiodorone, } \\
\text { radiographic contrast agents), lithium, interferon a, } \\
\text { sulfonamides }\end{array}$ \\
\hline Inadequate replacement therapy of hypothyroidism & $\begin{array}{l}\text { Inadequate dosage, noncompliance, drug interactions } \\
\text { (iron, calcium carbonate, dietary soy), increased } \mathrm{T}_{4}\end{array}$ \\
\hline
\end{tabular}


clearance (phenytoin, carbamazepine, phenobarbital),

malabsorption

\begin{tabular}{ll}
\hline$\beta$-thalassemia major & Due to hemosiderosis \\
\hline After bone marrow transplantation & \\
\hline Thyroid infiltration & $\begin{array}{l}\text { Amyloidosis, sarcoidosis, hemochromatosis, cystinosis, } \\
\text { primary thyroid lymphoma }\end{array}$ \\
\hline Obesity & \\
\hline Genetic & Loss-of-function mutations in TSHR, GNAS, PAX8, TTF-1, \\
\hline Laboratory interferences & DUOX2 \\
\hline
\end{tabular}

Table 1. Causes of SCH in children

\subsection{Transient hyperthyrotropinemia in newborns}

Hyperthyrotropinemia in newborns is mainly a physiological condition reflecting the TSH surge which occurs immediately after birth. Additional etiologies for this condition include iodine deficiency that is common in areas of endemic goiter or secondary to iatrogenic iodine overload during fetal and postnatal life. Significant exposure to iodine may be caused by transplacental crossing of iodine to the fetus or secretion of iodine into the breast milk consumed by the newborn. In addition, the newborn, and especially premature newborns, can be exposed to iodine overload through contrast medium in imaging studies or to iodine in topical agents. Rare causes of neonatal hyperthyrotropinemia are transplacental passage of thyroid-blocking antibodies and antithyroid drugs from mother to fetus in maternal autoimmune diseases. Genetic etiologies include TSH resistance (RTSH), mainly due to mutations in TSHR. Additional inherited defects include mutations in DUOX2, PAX8, TTF-1 and GNAS1. Long-term follow-up and laboratory and imaging evaluation are needed to define the specific etiology and to select the appropriate clinical approach in each case. Sakka et al. (2009) reported significant elevations in TSH levels in children born after in-vitro fertilization. The authors hypothesized that this might represent an epigenetic developmental abnormality related to preimplantation manipulation of the embryo.

\subsection{Maturation of thyroid hormone metabolism}

Fetal thyroid develops under the influence of increasing TSH levels during the last half of gestation. Serum TSH increases from low levels at 18 weeks to a peak of 7-10 mU/1 at term. Fetal hypothalamic-pituitary feedback matures during the second trimester (Fiser \& Klein, 1981; Fisher \& Polk, 1989; Rakover et al., 1999). More recent studies sampling fetal cord blood have shown measurable TSH levels at as early as 15 weeks gestation which peak in the second trimester and then plateau at that level until term (Hume et al., 2004; Thorpe-Beeston et al., 1991). At birth, in response to extrauterine exposure, there is acute release of TSH (TSH surge) that peaks at a concentration of about $70 \mathrm{mU} / 1$ at $30 \mathrm{~min}$ and remains elevated for 3 to 5 days 
after birth. The increase in $\mathrm{FT}_{4}$ levels at birth is $\mathrm{TSH}$-dependent. Increased $\mathrm{FT}_{4}$ secretion continues for 1 to 2 months after birth. Normal pediatric age-dependent references for thyroid hormones have shown TSH concentrations as high as $9.64 \mathrm{mIU} / \mathrm{l}$ in the first months after birth, suggesting that hyperthyrotropinemia in the first year of life reflects normal phenomena and does not necessarily require further evaluation or therapy (Hübner et al., 2002).

\subsection{Maternal Autoimmune Thyroid Diseases (AITDs)}

Transplacental transfer of thyroid-stimulating antibodies (TSAbs) and TSH binding inhibitor antibodies (TBIAbs) from mother to fetus has been described in the presence of maternal AITDs. In maternal Graves' disease, the infant is at risk for congenital hyperthyroidism (Ogilvy-Stuart et al., 2002), CH and euthyroid hyperthyrotropinemia (Fu et al., 2005). Fu et al. (2005) reported on 78 mothers with AITDs; about half of their babies had transient hyperthyrotropinemia, seven had overt hypothyroidism and one had hyperthyroidism (Fu et al., 2005). The severity of the clinical presentation correlated with the levels of maternal autoantibodies. Congenital hyperthyroidism resulted from maternal transfer of TSAbs. Transient $\mathrm{CH}$ or hyperthyrotropinemia resulted from the mother consuming anti-thyroid drugs such as metimazole and propylthiouracil, which have a short half life of a few days (Cheron et al., 1981), and from transplacental transfer of TBIAbs, which are eliminated from the infant's serum after a few months in parallel to the elimination of maternal immunoglublulins. Papendieck et al. (2009) described 28 newborns of mothers with Graves' disease diagnosed with neonatal hyperthyroidism (9 newborns), primary hypothyroidism (14) and central hypothyroidism (5). Spontaneous remission was shown in all of the affected babies between 16 days and 8 months apart from 2 babies who had permanent hypothyroidism. The authors concluded that infants born to mothers with Graves' disease should be assessed by a pediatric endocrinologist to better identify thyroid diseases in the offspring. In maternal Hashimoto's thyroiditis, the infant is at risk for transient $\mathrm{CH}$ or hyperthyrotropinemia due to transplacental transfer of TBIAbs. To determine the incidence of transient $\mathrm{CH}$ due to TRAbs, all dried neonatal blood specimens from the neonatal screening in North America were screened for TRAbs (Brown et al., 1996) and only 2\% of babies diagnosed with $\mathrm{CH}$ were positive for TRAbs, suggesting that maternal AITD is a rare etiology of $\mathrm{CH}$. The occurrence of transient hypothyroidism due to maternal Hashimoto's thyroiditis was reported mainly as a case report (Matsuura et al.,1980; Zakarija et al., 1990; Wada et al., 2000). We described transient CH in three siblings born to a mother with well-controlled Hashimoto's thyroiditis with extremely high levels of TBIAbs (Rakover et al., 1990). The baby had high TBIAbs concentrations and as reflected by sequential serum measurements, these antibodies disappeared after 4 months. In one sibling, the thyroid gland was absent in a ${ }^{99 \mathrm{~m}} \mathrm{TC}$ scan performed on the first days of life but repeated scan after the age of 2 years, revealed a gland of normal size and position. Absence of distal femoral epiphysis at birth was shown. Interestingly, the three siblings had minor abnormal neurological signs in late childhood such as dyslexia, attention deficit disorder and coordination disorders. These neurological findings, along with the lack of distal femoral epiphysis at birth, suggested in-utero fetal hypothyroidism. A less favorable intellectual outcome was reported in babies with transient $\mathrm{CH}$ born to mothers positive for TBIAbs compared to babies with permanent hypothyroidism of other etiologies, especially if unrec- 
ognized maternal hypothyroidism was present in utero (Matsuura et al., 1990; Wada et al., 2000). Our findings as well as other reports raised the dilemma of whether prenatal follow-up, after umbilical cord blood sampling and intra-amnionic ${\mathrm{L}-\mathrm{T}_{4}}_{4}$ injections, if indicated, is required to prevent late neurological sequels in these cases (Abalovich et al., 2007; De Groot et al., 2012; Wada et al., 2000). It is recommended that all babies born to mothers with AITDs be reviewed in the first 3 days of life and a thyroid function test be taken to identify those babies with transient $\mathrm{CH}$ that require $\mathrm{L}_{-} \mathrm{T}_{4}$ therapy, or babies with congenital hyperthyroidism requiring anti-thyroid drugs (Ogilvy-Stuart et al., 2002). The approach for in-utero treatment of fetal thyroid disease is still a matter of debate (De Groot et al., 2012).

\subsection{Exposure to iodine}

Abnormal thyroid function due to either iodine deficiency or iodine overload has been described in prenatal and postnatal periods. In cases of iodine overload, the Wolff-Chaikoff mechanism blocks the uptake of iodine by the thyroid gland resulting in reduced $\mathrm{T}_{4}$ production and in turn increased TSH secretion via a negative feedback mechanism. Sava et al. (1984) showed that newborns from areas of iodine deficiency in Sicily were at higher risk for hyperthyrotropinemia; the increase in risk was related to the degree of iodine deficiency as reflected by iodine cord blood measurements. On recall, only two patients were diagnosed with $\mathrm{CH}$ which required $\mathrm{L}_{-} \mathrm{T}_{4}$ therapy for as long as 1 year. The authors suggested the need for maternal iodine prophylaxis therapy in areas of endemic iodine deficiency. Transient thyroid function abnormalities have also been observed in neonates born to mothers with excessive iodine intake. Maternal iodine exposure was reported accompanying excess iodine in the diet (Nishiyama et al., 2004), use of iodine compounds such as povidone iodine in topical applications, exposure to contrast medium during pregnancy and the use of antiseptic agents in obstetric departments (Grüters et al., 1983). Prenatally, maternal iodine crosses the placenta and concentrates in the fetal thyroid gland, whereas postnatally, the newborn is exposed to iodine through the breast milk (Chanoine et al., 1988; Koga et al., 1995). Premature babies are particularly susceptible to iodine-induced hypothyroidism due to immaturity of the thyroidpituitary negative feedback mechanism and to higher exposure to iodine-containing agents in intensive care (Delange et al., 1984). Uses of iodine in Cesarean sections and in neonatal intensive care units are additional causes for newborn iodine overload and therefore it is recommended to avoid iodine compounds in deliveries and in the neonate intensive care units. In newborns, exposure to iodine may be attributed to umbilical iodine application as well. Iodine overload may cause either transient hyperthyroidism with symptoms of tachycardia and failure to gain weight (Rakover \& Adar, 1989) or may present as $\mathrm{CH}$ or persistent hyperthyrotropinemia. Nishiyama et al. (2004) described 15 babies with transient $\mathrm{CH}$ or persistent hyperthyrotropinemia born to mothers in Japan who consumed a high iodine diet during their pregnancies; among them, 12 babies were treated with $\mathrm{L}_{-} \mathrm{T}_{4}$. The authors recommended that food be labeled with their precise amount of iodine to avoid high intake of iodine by pregnant women. $\mathrm{CH}$ and hyperthyrotropinemia in cases of iodine overload or deficiency are transitory; however, whether transient hypothyroidism or hyperthyrotropinemia can result in permanent neurological sequels in these cases is not clear, and it is therefore recommended that sort-term $\mathrm{L}-\mathrm{T}_{4}$ therapy be considered on an individual basis. 


\section{Genetic etiology of SCH}

\subsection{TSH Resistance syndrome (RTSH)}

RTSH is a condition in which thyroid cells show reduced sensitivity to TSH. This condition is characterized by elevated serum TSH concentration, a normal or hypoplastic thyroid gland and normal to very low levels of thyroid hormones (Refetoff, 2003). The diagnosis of RTSH defect is based on the absence of thyroid antibodies, a lack of goiter, measurable serum thyroglobulin, and familial occurrence of hyperthyrotropinemia or hypothyroidism. Most of the cases of RTSH are attributed to mutations in the TSHR but in many cases, no such mutations were found, suggesting that additional genes are associated with RTSH syndrome (Xie et al., 1997). The diagnostic work-up of RTSH should exclude PAX8 mutations, which are characterized by thyroid dysgenesis associated with kidney abnormalities (Grüters et al., 2003; Park \& Chatterjee, 2005) and mutations in GNAS1, which encodes Gs $\alpha$ subunit, causing pseudohypoparathyroidism (PHP). Another form of RTSH is an autosomal dominantly inherited disease characterized by euthyroid hyperthyrotropinemia, for which the specific gene has not yet been identified. This condition has been linked to a locus on chromosome 15q25.3-26.1 (Grasberger et al., 2005). Loss-of-function mutations of DUOX genes are an additional cause for transient hyperthyrotropinemia.

\subsection{TSH Receptor (TSHR)}

Loss-of-function mutations in TSHR manifest with a variable clinical spectrum of phenotypes ranging from severe uncompensated $\mathrm{RTSH}$ presenting with $\mathrm{CH}$, or partially compensated RTSH presenting with SCH or even with normal thyroid function (for review see TenenbaumRakover, 2012). CH is commonly detected by TSH-based neonatal screening but may missed by total $\mathrm{T}_{4}\left(\mathrm{TT}_{4}\right)$-based screening since, in many cases, $\mathrm{TT}_{4}$ levels are within the normal range at birth. The degree of $\mathrm{CH}$ is variable and depends on the genotype. Severe forms manifest as overt $\mathrm{CH}$; moderate forms manifest as hypothyroidism identified by neonatal screening without clinical symptoms of hypothyroidism and mild forms present with hyperthyrotropinemia and normal thyroid hormone levels. Most of the described cases of $\mathrm{CH}$ are detected by neonatal screening with elevated TSH and normal $\mathrm{TT}_{4}$ levels, but without any clinical symptoms or signs of hypothyroidism (de Roux et al., 1996; Tenenbaum-Rakover et al., 2009). Nevertheless, ${\mathrm{L}-\mathrm{T}_{4}}_{4}$ therapy is initiated in most cases to prevent future consequences of untreated $\mathrm{CH}$. At the age of 2 to 3 years, when $\mathrm{L}_{-} \mathrm{T}_{4}$ is withdrawn, thyroid hormones remain low in the severe mutations; however in milder mutations, despite extremely elevated TSH levels, thyroid hormone levels are normal, indicating compensated hypothyroidism (Tenenbaum-Rakover et al., 2009). ${ }^{99 \mathrm{~m} T C}$ scan commonly reveals a normal or hypoplastic gland but in some cases, an absence of thyroid gland has been demonstrated, suggesting thyroid agenesis. On the other hand, the presence of detectable thyroglobulin as well as the demonstration of a thyroid gland in the normal position in ultrasonographic imaging exclude thyroid agenesis and indicate a diagnosis of RTSH. The affected patients who are not identified by neonatal screening are commonly identified by routine laboratory tests in childhood or even as adults and are commonly asymptomatic. Most of the described cases are heterozygous for 
TSHR mutations, but biallelic mutations have been reported as well. To date, about 50 different TSHR mutations have been reported, presenting with a spectrum of phenotypes ranging from overt $\mathrm{CH}$ to mild euthyroid hyperthyrotropinemia. Subjects with euthyroid hyperthyrotropinemia commonly have stable TSH levels and do not develop overt hypothyroidism with time. The phenotype correlates with the genotype as the latter is reflected in the severity of hyperthyrotropinemia and the decrease in $\mathrm{FT}_{4}$ levels. Screening for TSHR mutations should be considered in individuals with apparent nonautoimmune SCH. In view of the variability in phenotypes and outcomes among individuals with this condition, careful long-term followup is recommended and replacement therapy should be considered on an individual basis according to thyroid hormone levels in the clinical context. In cases with loss-of-function mutations in TSHR presenting with $\mathrm{CH}$, early initiation of $\mathrm{L}-\mathrm{T}_{4}$ therapy is recommended to prevent late-effect consequences of hypothyroidism as in other etiologies of $\mathrm{CH}$. However, withdrawal of $\mathrm{L}_{-} \mathrm{T}_{4}$ at the age of 2 to 3 years revealed transient hypothyroidism in some cases, putting the need for lifelong replacement therapy into question (Alberti et al., 2002; Tenenbaum-Rakover et al., 2009). SCH caused by TSHR mutations with mild to moderate loss of function maintains stable compensated RTSH and may not necessitate thyroid hormone replacement. Moreover, most patients with RTSH do not present with symptoms of hypothyroidism or with biochemical parameters of uncompensated hypothyroidism, such as elevated creatinine phosphokinase (CPK) and liver enzymes and hyperlipidemia (Tenenbaum-Rakover et al., 2009). The presence of normal $\mathrm{FT}_{4}$ levels argues against the need for replacement treatment, especially when inadvertent overtreatment, producing subclinical hyperthyroidism, can have undesirable effects (Samuels et al., 2008). Contrasting with this approach, it has been shown that some subjects with RTSH have a slight decrease in $\mathrm{FT}_{4}$ levels compared to controls, although remaining within the normal range, which may point to a condition of compensated hypothyroidism in these affected patients. In addition, the possibility of secondary pituitary enlargement in patients with extreme hyperthyrotropinemia may support $\mathrm{L}-\mathrm{T}_{4}$ replacement therapy. In view of the variability in phenotypes for the different types of mutations, as well as between individuals with the same genotypes, it is recommended that careful follow-up and cautious administration of $\mathrm{L}_{-} \mathrm{T}_{4}$ be considered based on individual thyroid hormone levels in the clinical context.

\subsection{Pseudohypoparathyroidism (PHP)}

Loss-of-function mutations in GNAS1, which encodes Gs $\alpha$ subunit, cause PHP and lead to a syndrome of resistance to multiple G-coupled receptor hormones. Resistance to parathyroid hormone (PTH) is the main feature of PHP (Mantovani, 2011; Mantovani et al., 2002). RTSH is commonly clinically manifested during childhood or adulthood but may present at birth as $\mathrm{CH}$ identified by neonatal screening. In most cases, hypothyroidism is mild and may present with hyperthyrotropinemia for long durations without any clinical symptoms of hypothyroidism. ${ }^{99 \mathrm{~m}} \mathrm{TC}$ scan generally demonstrates a hypoplastic gland in a normal position but absence of a thyroid gland, demonstrated by ultrasonographic imaging, has been reported as well. SCH is the presenting laboratory finding of PHP in many cases. RTSH is commonly found in PHP-Ia but is also reported in PHP-Ib. The phenotype of patients with PHP-Ia includes Albright osteodystrophy presenting with brachydactyly, round face, short stature, central 
obesity, subcutaneous ossifications and variable degree of mental retardation. Clinicians should be aware of this rare syndrome; in those cases of $\mathrm{SCH}$ occurring in obese subjects or with Albright osteodystrophy phenotype, PHP should be suspected and further hormonal and molecular evaluations should be considered.

\subsection{Dual Oxidase maturation factor (DUOX)}

Loss-of-function mutations in DUOX have been reported in children with $\mathrm{CH}$ and in transient hyperthyrotropinemia of the newborn (De Marco et al., 2011; Hoste et al., 2010; Maruo et al., 2008; Moreno et al., 2002). Hydrogen peroxide $\left(\mathrm{H}_{2} \mathrm{O}_{2}\right)$ is an essential co-substrate for oxidation of iodine and iodination of thyroglobulin by the thyroid peroxidase (TPO) enzyme. DOUX1 and DOUX2 proteins have a crucial role in $\mathrm{H}_{2} \mathrm{O}_{2}$ generation and therefore in thyroid hormone synthesis. The structure of these proteins includes seven putative transmembrane domains. Moreno et al. (2002) showed that biallelic mutations of DUOX2 result in organification defect presenting with permanent $\mathrm{CH}$, whereas monoallelic mutations result in transient $\mathrm{CH}$ or hyperthyrotropinemia (OMIM\#606758) (Moreno et al., 2002). In contrast, sequencing of DUOX2 in Japanese children diagnosed with transient congenital hyperthyrotropinemia revealed eight novel mutations of the DUOX2 gene, all with biallellic mutations (Maruo et al., 2008). The authors concluded that even complete inactivation of DUOX2 causes transient, but not permanent $\mathrm{CH}$, due to the presence of DUOX1, which maintains the supply of $\mathrm{H}_{2} \mathrm{O}_{2}$ required for oxidation after the neonatal period. However, late onset of hypothyroidism or $\mathrm{SCH}$ may appear in adulthood during periods of increased requirement for thyroid hormones, such as in pregnancy (Ohye et al., 2008). The organification defect is characterized by normal position and location of the thyroid gland in a ${ }^{99 \mathrm{~m}} \mathrm{TC}$ scan, high iodine uptake with partial positive perchlorate discharge test. Goiter may be present or develop over time (Moreno et al., 2002; Ohye et al., 2008).

\subsection{Thyroid dysgenesis}

Three transcription factors have been identified as involved in thyroid development: TTF-1, TTF-2 and PAX8. The discovery of these transcription factors in a knockout mouse model was followed by descriptions of the phenotypes in humans. Human mutations in TTF-2 are very rare and present with $\mathrm{CH}$, cleft palate and spiky hair (OMIM\#602617). Patients with TTF-1 and PAX8 mutations present with either $\mathrm{CH}$ or persistent congenital hyperthyrotropinemia; the former are associated with lung and neurological involvement while the latter are associated with kidney abnormalities.

\subsubsection{TTF-1 mutations}

TTF-1, also known as NKX2.1, is a transcription factor involved in thyroid development. Ttf1null mice were born dead, lacking a thyroid gland, lung parenchyma and pituitary gland, and with severe defects in the ventral forebrain. Heterozygous mice presented a euthyroid phenotype with reduced motor-coordination skills (Park \& Chatterjee, 2005). In humans, TTF-1 mutations have been reported in children presenting with $\mathrm{SCH}$, lung involvement presenting with neonatal respiratory distress and neurological involvement presenting with hypotonia, 
persistent ataxia, dysarthria, microcephaly, choreathetosis and developmental delay (OMIM \#600635). TTF-1 mutations are inherited in an autosomal dominant manner. Patients present with variable thyroid phenotypes ranging from permanent severe $\mathrm{CH}$ to persistent congenital hyperthyrotropinemia resembling RTSH (Devriendt et al., 1998; Krude et al., 2002; Pohlenz et al., 2002) with hypoplasticity or agenesis of the thyroid gland or the gland in a normal position (Krude et al., 2002). TTF-1 mutations may also present with isolated benign hereditary chorea without thyroid phenotype (Breedveld et al., 2002).

\subsubsection{PAX8 mutations}

PAX8 is thyroid transcription factor which is a key gene in mammalian embryonic development. Homozygous Pax8-null mice die shortly after weaning and their survival is dependent on thyroxin replacement therapy. Mutations in the PAX8 gene in humans are characterized by thyroid dysgenesis associated with kidney abnormalities (Damante 1998; Grüters et al., 2003; Narumi et al., 2011; Park \& Chatterjee, 2005; Vilain et al., 2001) inherited in an autosomal dominant manner (OMIM\#167415). The thyroid gland is hypoplastic (Vilain et al., 2001) or in an ectopic location. Partial organification defect and partial iodide transport defect have been reported (Jo et al., 2010). To date, 31 mutations have been described in the PAX8 gene, presenting as permanent $\mathrm{CH}$ or as mild SCH (Narumi et al., 2011; Narumi et al., 2012). Screening for $P A X 8$ gene mutations in 300 Chinese patients with $\mathrm{CH}$ revealed only two subjects with heterozygous $P A X 8$ mutations, suggesting that $P A X 8$ mutation is a very rare etiology for CH (Liu et al., 2012).

\section{Outcome of neonatal hyperthyrotropinemia}

Neonatal hyperthyrotropinemia may be transitory or permanent. Transient congenital hyperthyrotropinemia has been shown in iodine deficiency or due to iodine overload and in both of these cases, full recovery is expected within days to a month after the cause has been removed. In maternal AITD, TRAbs disappear within 4 to 8 months. A less favorable intellectual outcome was reported in these cases, probably due to in-utero fetal hypothyroidism (Matsuura et al., 1990; Wada et al., 2000). In cases of persistent congenital hyperthyrotropinemia, minor thyroid abnormalities (Calaciura et al., 2002; Daliva et al., 2000; Leonardi et al., 2008; Miki et al., 1989; Zung et al., 2010) have been reported in late childhood. Longitudinal studies assessing the outcome of subjects with neonatal hyperthyrotropinemia have shown a prevalence of $50 \% \mathrm{SCH}$ with morphological alterations of the thyroid in early childhood (3 years) (Calaciura et al., 2002), which decreases in follow-up to $30 \%$ in late childhood (8 years), suggesting that persistent hyperthyrotropinemia represents minor congenital thyroid abnormalities (Leonardi et al., 2008). In about $50 \%$ of the subjects morphological, immunological or genetic abnormalities were found. A high rate of thyroid autoantibodies was identified at the age of 2 to 3 years in about 25\% of the subjects (Calaciura et al., 2002); morphological changes such as enlarged or hypoplastic thyroid gland or its hemiagenesis were shown in $10 \%$ of the cases. Zung et al. (2010) showed that subjects with persistent vs. transient hyperthyrotropinemia had a higher rate of abnormal thyroid imaging and therefore thyroid imaging was 
recommended to distinguish between the persistent and transient forms. Moreover, genetic analysis revealed heterozygous mutations of TPO and TSHR (Calaciura et al., 2002) in about $5 \%$ of the children with $\mathrm{SCH}$ following transient neonatal hyperthyrotropinemia. These findings indicate that hyperthyrotropinemia at birth may represent an inherited thyroid disease that interferes with thyroid hormone synthesis or thyroid genesis. In contrast to these studies, Köhler et al. (1996) showed no increase in the risk of thyroid abnormalities and normal neurological development as well as normal growth in children with hyperthyrotropinemia at birth; they therefore recommended avoiding longitudinal surveys of these children to prevent parents' anxiety (Köhler et al., 1996). In summary, neonatal hyperthyrotropinemia may be persistently associated with either autoimmune disease, inherited thyroid hormone synthesis defects or morphological changes, and therefore long-term follow-up throughout childhood is recommended in cases where TSH levels are persistently above the normal range during the first year of life.

\section{Pediatric-age-dependent thyroid hormone reference}

The commonly available normal reference range provided by commercial companies for thyroid hormone levels in routine laboratories is for adults. Using this may result in an erroneous interpretation of the results of thyroid function in children. Moreover, great variability exists between the pediatric references published in the literature (Elmlinger et al., 2001; Hübner et al., 2002; Kapelari et al., 2008; Soldin et al., 2009; Strich et al., 2012; Zurakowski et al., 1999). The variability in the normal reference range is attributed to different types of assays, different ethnic and age groups and different sample sizes. Even in the same assay, different laboratories can provide different normal ranges (Hübner et al., 2002; Kapelari et al., 2008; Strich et al., 2012). The variability between assays results from the different standards, antibodies and methods used [two-site immunoassay commonly gives lower results than radioimmunoassays (RIAs)]. Furthermore, the references established for children in different age groups make use of different populations; for example, hospitalized children (Hübner et al., 2002; Kapelari et al., 2008) have lower $\mathrm{FT}_{3}$ concentration due to non-thyroidal illness, whereas references using routine laboratory samples (Strich et al., 2012) may include samples from children bearing unidentified thyroid diseases, which may cause an upward bias in the TSH levels. Despite these limitations, it is still clear that childhood references are very different from adult references. Strich et al. (2012) showed that in 11,000 samples of children aged 0 to 18 years taken from a routine laboratory database, the upper limit of TSH was $1 \mathrm{mIU} / \mathrm{ml}$ above the provided reference and the lower normal range of $\mathrm{FT}_{3}$ was 0.5 to $2 \mathrm{pmol} / \mathrm{l}$ higher than the reference. Hübner et al. (2002) analyzed thyroid hormone levels in children with the ADVIA® Centaur ${ }^{\mathrm{TM}}$ analyzer. They showed elevated TSH levels in the first year of life with an upper limit of $9.64 \mathrm{mIU} / \mathrm{l}$, which decreased gradually to $4.9 \mathrm{mIU} / \mathrm{l}$ at the age of 18 years. The same trend was shown with $\mathrm{FT}_{4}$, decreasing from 17.2 to $14.7 \mathrm{pmol} / \mathrm{l}$ from 1 to 18 years of age. The upper limit of $\mathrm{FT}_{3}$ levels showed the same, albeit less pronounced trend, from 8.2 to $6.63 \mathrm{pmol} /$ 1. The authors suggested using continuous-age-dependent reference ranges in children who show better agreement with biological reality, as these are more reliable than discontinuous 
reference ranges. No significant sex-specific effects on age-adjusted hormone levels were shown (Hübner et al., 2002; Kapelari et al., 2008). In recent years, there has been some controversy regarding the normal TSH range for adult populations following the laboratory guidelines from the National Academy of Clinical Biochemistry, indicating that $85 \%$ of normal adult individuals have TSH levels below $2.5 \mathrm{mIU} / \mathrm{l}$. These findings raised a debate over whether subjects with TSH levels above $2.5 \mathrm{mIU} / 1$ have $\mathrm{SCH}$ and should be further followed-up by repeated TSH measurements (Surks et al., 2004; Wartofsky \& Dickey, 2005). In summary, agedependent references should be used to interpretate thyroid functions in childhood. Hyperthyrotropinemia as high as $6.0 \mathrm{mIU} / 1$ (Hübner et al., 2002) with normal thyroid hormone levels and without clinical symptoms, during the first months of life can be considered within the upper normal limit for age and therefore not requiring $\mathrm{L}-\mathrm{T}_{4}$ therapy. Follow-up with repeated thyroid function tests is recommended in cases of persistent hyperthyrotropinemia to identify those infants which may develop late onset overt hypothyroidism.

\section{Laboratory pitfalls}

In about 0.5 to $5 \%$ of patient samples, hyperthyrotropinemia with normal thyroid hormone levels results from laboratory interference (Ismail et al., 2002). Such interference includes the presence of heterophilic antibodies, rheumatic factor (RF), autoimmune antithyroid hormone antibodies and the presence of macro-TSH.

\subsection{Heterophilic antibodies}

Heterophilic antibodies are antibodies produced against poorly defined antigens of various animal immunoglobulins. The best known heterophilic antibodies are human antimouse antibodies (HAMAs). Since immunometric assays use animal antihuman antibodies, the presence of human antimouse immunoglobulins in an individual's serum could interfere with the antigen-antibody binding reaction, resulting in falsely high or low hormonal levels. This interference is very rare in competitive RIAs but well recognized in the two-site sandwich immunometric assays (Després \& Grant, 1988; Halsall et al., 2009; Kaplan \& Levinson, 1999). High false-positive results are commonly reported in the latter, whereas false low levels are reported in competitive RIAs. High levels of $\alpha$-fetoprotein, human chorionogonadotropin, follicle-stimulating hormone, luteinizing hormone, ferritin and tumor markers were described in TSH measurements secondary to the presence of heterophilic antibodies. Since TSH is commonly measured in routine evaluations for various medical complaints, elevated TSH level due to the presence of heterophilic antibodies is not a rare finding. Transient neonatal hyperthyrotropinemia identified by neonatal screening was reported by Czernichow et al. (1981), attributed to maternal heterophilic antibodies. The antibodies disappeared from the circulation within 2 months in the infants and within 4 to 6 months in the mothers (Czernichow et al., 1981). When heterophilic interference is suspected, further evaluation is indicated. The first step is to assess the sample using other immunoassays with different antibodies. The sample should be remeasured after dilution (Ross et al., 2008). Nonlinearity in sample dilution indicates the presence of laboratory interference. Preincubation of a patient's sample with 
antiheterophilic tube or mouse serum confirms the diagnosis of heterophilic antibodies. The clinician should be aware that hyperthyrotropinemia with normal thyroid hormone levels and without clinical symptoms of hypothyroidism in the newborn or in childhood may be the result of interference by heterophilic antibodies. The diagnosis of hyperthyrotropinemia due to heterophilic antibodies cancels the need for further expensive laboratory and imaging investigations and avoids unnecessary $\mathrm{L}-\mathrm{T}_{4}$ therapy.

\subsection{Thyroid hormone autoantibodies}

Thyroid hormone autoantibodies are present in about 1 to $7 \%$ of patients with autoimmune thyroid diseases, mainly Graves' disease. Antibodies against thyroglobulin and thyroid peroxidase are very common in Hashimoto's thyroiditis and Graves' disease; however, antibodies against thyroid hormones $\mathrm{T}_{3}$ and $\mathrm{T}_{4}$ are less common and anti-TSH autoantibodies are even rarer. The presence of thyroid hormone autoantibodies interferes with the assay procedure, giving higher hormonal levels (Després \& Grant, 1998). We had one case of a 16year-old girl with Graves' disease (unpublished data) who presented with severe symptoms of hypothyroidism, 4 months after $8 \mathrm{mCi}$ of I-131 therapy, with bradycardia and excessive weight gain. Thyroid function was confusing, with extremely high TSH $136 \mathrm{mIU} / \mathrm{dl}$ (0.35-5.5 $\mathrm{mIU} / \mathrm{dl})$, extremely high $\mathrm{FT}_{4}>6(0.88-12.76 \mathrm{ng} / \mathrm{ml})$; low $\mathrm{FT}_{3} 30 \mathrm{ng} / \mathrm{dl}(60-180 \mathrm{ng} / \mathrm{dl})$ and extremely high thyroid stimulating immunoglobulin (TSI) $164 \mathrm{IU} / \mathrm{l}$, anti-TPO $>1000 \mathrm{U} / \mathrm{ml}$ and antithyroglobulin $>3000 \mathrm{U} / \mathrm{ml}$. Measuring $\mathrm{FT}_{4}$ in another assay using different antibodies revealed low $\mathrm{FT}_{4}$, confirming the clinical diagnosis of hypothyroidism post-radioactive iodine therapy. The increase in $\mathrm{FT}_{4}$ and TSI concentrations was associated with the autoimmune overreaction post-I-131 therapy with production of anti-FT $\mathrm{F}_{4}$ autoantibodies. This case demonstrates the importance of being aware of the existence laboratory interferences for making correct clinical decisions.

\subsection{Macro-TSH}

Macro-TSH is a macromolecule that is formed when anti-TSH IgG combines with a TSH molecule. Due to their large size, these macromolecules are less efficiently cleared from the circulation by the kidneys, and therefore accumulate in the serum. Since they are nonfunctioning, they have no clinical significance and therefore may lead to unnecessary therapy. This condition is commonly described in patients with asymptomatic hyperprolactinemia caused by macroprolactinemia (Batista et al., 2012). Macro-TSH is rarer than macroprolactinemia with only about 13 cases described to date (Halsall et al., 2006; Loh et al., 2012; Mendoza, 2009; Newman et al., 2006; Rix et al., 2011; Sakai et al., 2009). The presence of macro-TSH should be suspected when the patient is asymptomatic and has elevated TSH level which does not correlate with additional thyroid function. Nonlinearity when the subject's serum is diluted indicates the presence of interfering antibodies. The presence of macro-TSH is proven by adding polyethylene glycol (PEG) to the patient's serum. Recovery results less than 50 to 30\% of the pre-PEG results indicate the presence of macro-TSH. The diagnosis of macro-TSH is confirmed by gel-filtration chromatography but this technique is not routinely available. The presence of macro-TSH is not part of AITD or autoimmunity. Misdiagnosis of $\mathrm{CH}$ identified 
by TSH-based neonatal screening was described in newborns which were later found to have macro-TSH of maternal origin (Halsall et al., 2006; Newman et al., 2006; Rix et al., 2011). It is suggested that maternal TSH levels be measured in cases of euthyroid neonates with elevated serum TSH and normal thyroid hormone. When maternal TSH is persistently elevated, the presence of macro-TSH should be considered. Further analysis, including recovery with PEG, is indicated to avoid unnecessary $\mathrm{L}_{-} \mathrm{T}_{4}$ treatment. Macro-TSH spontaneously disappears from the infant's serum at the age of 6 to 8 months in parallel with the elimination of maternal immunoglobulins.

In summary, clinicians should be aware of false laboratory results attributed to interference in the immunoassay methods, mainly in evaluating euthyroid hyperthyrotropinemia. In cases in which there are discrepancies between the clinical presentation and the laboratory results, antibody interference should be suspected. This may be followed up by further laboratory evaluation. Accurate diagnosis leads to a better clinical approach and may allow avoiding unnecessary treatment.

\section{Obesity and hyperthyrotropinemia}

Obesity in children has become a great medical concern in the last two decades. Thyroid function tests are part of the diagnostic work-up in children who are overweight or obese. Moderate elevation in TSH levels in up to $20 \%$ of obese children has been demonstrated in many studies (Eliakim et al., 2006; Grandone et al., 2010; Reinehr, 2011; Reinehr et al., 2006; Shalitin et al., 2009). Among them, only 7 to $20 \%$ showed positive thyroid autoantibodies (Eliakim et al., 2006; Grandone et al., 2010). It has been speculated that hyperthyrotropinemia in obesity is a result of elevated leptin which stimulates the hypothalamic-pituitary-thyroid axis (Reinehr, 2011). The question is whether the elevation in TSH is the cause for or a

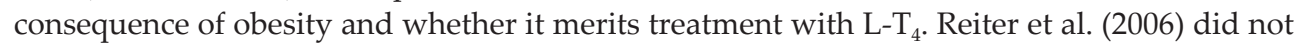
find any association between hyperthyrotropinemia and lipid profile, whereas Shalitin et al. (2009) showed a positive correlation between hyperthyrotropinemia and waist circumference and triglyceride levels, supporting the need to treat those children. The fact that hyperthyrotropinemia was accompanied by normal $\mathrm{FT}_{4}$ and elevated $\mathrm{FT}_{3}$ levels (Reinehr et al., 2006) disagrees with the hypothesis of $\mathrm{SCH}$ as the cause for obesity in these children. Moreover, weight loss led to a significant reduction in TSH levels (Eliakim et al., 2006; Grandone et al.,

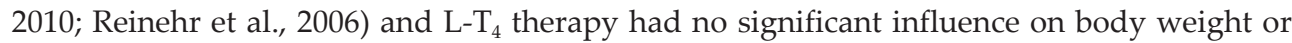
lipid profile (Eliakim et al., 2006). Most of the studies agree that hyperthyrotropinemia in obesity is a consequence rather than a cause, and therefore $\mathrm{L}_{-} \mathrm{T}_{4}$ therapy is unnecessary in obese children (Eliakim et al., 2006; Grandone et al., 2010; Reinehr, 2011; Reinehr et al., 2006).

\section{Autoimmune Thyroid Disease (AITD) - Hashimoto's thyroiditis}

Hashimoto's thyroiditis is characterized by the presence of thyroid autoantibodies [antithyroid peroxidase (TPO) and anti-thyroglobulin (TG)], with or without goiter. This condition 
is characterized by hypoechogenicity of the thyroid gland in ultasonographic imaging and lymphocytic infiltration of the gland in fine-needle aspiration. The disease commonly appears in adolescence, with predominantly females affected. Among children with acquired hypothyroidism, $66 \%$ had AITD (Hunter et al., 2000), and about 30\% to 50\% had a family history of thyroid diseases (de Vries et al., 2009). The risk of overt hypothyroidism in adults with thyroid autoantibodies is estimated at $4.3 \%$ per year (Vanderpump \& Tunbridge, 2002); however, there are only a few pieces of data on the natural history of Hashimoto's thyroiditis in children (Gopalakrishnan et al., 2008; Jaruratanasirikul et al., 2001; Moore, 1996; Radetti et al., 2006; Rallison et al., 1991). Hypoechogenicity of the thyroid gland in ultrasound imaging is a useful tool for the diagnosis of AITD (Marcocci et al., 1991; Pedersen et al., 2000; Wolgang et al., 2002), showing higher sensitivity than the thyroid autoantibody tests (100 vs. 63.3\%) (Rago et al., 2001). Marwaha et al. (2008) showed that among children with hypoechogenic appearance of the gland, $41.4 \%$ were positive for FNA, 30.6\% were positive for TPO antibodies and 46.8\% showed abnormal thyroid function. They concluded that ultrasound echogenicity is useful tool for the diagnosis of AITD in children but less sensitive compared to adults (Marwaha et al., 2008). Moreover, the occurrence of hypoechogenicity has been found to predict evolution toward hypothyroidism over time in euthyroid subjects (Marcocci et al., 1991; Rago et al., 2001). Disagreement also exists with regard to the criteria for $\mathrm{L}_{-} \mathrm{T}_{4}$ therapy in childhood SCH (de Vries et al., 2009; Padberg et al., 2001; Radetti et al., 2006; Svensson et al., 2006). Thyroid function in Hashimoto's thyroiditis in children at presentation is variable. Özen et al. (2011) found that $36.7 \%$ of children were euthyroid, $32.7 \%$ had $\mathrm{SCH}, 16.6 \%$ were hypothyroid, $7.9 \%$ had subclinical hyperthyroidism and $5.9 \%$ presented with hyperthyroidism (Hashitoxicosis) (Özen et al., 2011). The main complaint was goiter presenting in $57.85 \%$ of patients, most of which were female (5.7:1, F:M). Similar findings were found by others showing that about $70 \%$ of children are either euthyroid or have SCH (Demirbilek et al., 2007; de Vries et al., 2009; Skarpa et al., 2011). Moore (1996) showed a benign course of SCH in children and adolescents with AITD and therefore suggested careful follow-up rather than treating them empirically. Gopalakrishnan et al. (2008) found that only $12.5 \%$ of children with either goiterous euthyroid or SCH develop overt hypothyroidism within 2 years. In contrast, Jaruratanasirikul et al. (2001) showed that $50 \%$ of subjects with SCH develop overt hypothyroidism within 5 years, supporting the need for long-term monitoring of thyroid function in patients with thyroid autoantibodies. de Vries et al. (2009) suggested that L- $\mathrm{T}_{4}$ therapy of euthyroid children with AITD, if appropriately monitored, is not harmful and may even be beneficial. Further benefit consisted of reducing thyroid volume in those patients with goiter with or without overt hypothyroidism (Svensson et al., 2006). Padberg et al. (2001) demonstrated that prophylactic L-T $\mathrm{T}_{4}$ therapy of patients with euthyroid AITD reduces both serological and cellular markers of autoimmune thyroiditis, indicating that $\mathrm{L}_{-} \mathrm{T}_{4}$ therapy might be useful for stopping progression of the disease. In contrast, the findings in an adult population that unnecessary long-term thyroxine therapy or overdose is associated with increase risk for osteopenia, cardiac disease and other harmful effects (Samuels et al., 2008) argues against regular therapy in children with AITD-associated SCH. 


\section{Natural history}

The annual rate of progression of SCH to overt hypothyroidism (elevated TSH with low thyroid hormones) in an adult population was $4.3 \%$ in women with positive thyroid autoantibodies and only $2 \%$ when antibodies were negative (Biondi \& Cooper, 2008). Huber et al. (2002), in a prospective study, found that $28 \%$ of women with SCH developed overt hypothyroidism after 10 years of follow-up. In children, the risk for progression to overt hypothyroidism is less common and recovery is more frequent. About $25 \%$ of subjects with goiterous thyroiditis had spontaneous remission and 33\% developed hypothyroidism over 20 years of follow-up (Rallison et al., 1991). Radetti et al. (2006) showed, retrospectively, in 160 children with AITD in an over 5-year follow-up that abnormal thyroid functions occur in $34.3 \%$ at presentation whereas $47.55 \%$ had abnormal thyroid function at last visit. However, $10 \%$ of patients with $\mathrm{SCH}$ became euthyroid. TSH concentrations showed large fluctuations over time. The presence of goiter and elevated thyroid autoantibodies at presentation together with an increase in thyroid autoantibodies and TSH levels in the course of the follow-up were predictive factors for development of overt hypothyroidism. After 5 years, more that $50 \%$ became or remained euthyroid, and therefore a poor predictive outcome could be shown in individual patients. The authors suggested that medical therapy should be considered only when significant deterioration of thyroid function appears (Radetti et al., 2006).

\section{Treatment}

The dilemma of whether to treat children with SCH is a matter of debate. The risk of developing overt hypothyroidism in an adult population with $\mathrm{SCH}$ was estimated at between 2 to $4.3 \%$ per year, with higher occurrence in patients with positive thyroid autoantibodies and increased TSH at presentation (Vanderpump \& Tunbridge, 2002). In adults, despite extensive studies and discussion, two different approaches still exist; one expert panel reviewed the available evidence and concluded that patients with TSH above $10 \mathrm{mIU} / 1$ with normal $\mathrm{FT}_{4}$ levels may be treated, whereas subjects with TSH between 4.5 and $10 \mathrm{mIU} / 1$ should be followed-up without treatment considering the adverse effects of $\mathrm{L}-\mathrm{T}_{4}$ on mineral health and heart and the lack of evidence to support the benefits of the treatment (Surks et al., 2004). On the other hand, a joint statement of experts from three endocrine societies (American Association of Clinical Endocrinologists, American Thyroid Association, Endocrine Society) recommended treatment of subjects with TSH between 4.5 and $10 \mathrm{mIU} / \mathrm{l}$, arguing that lack of evidence does not necessarily mean lack of benefit (Gharib et al., 2004). Moreover, in view of the recent suggestion to revise the reference range for adult TSH from 0.3 to $3 \mathrm{mIU} / 1$ by the National Health and Nutrition Examination Survey in United States, indicating that values above this range can be considered early thyroid failure, additional subjects will be included in the range of TSH within which thyroxine therapy is justified (Hollowell et al., 2002). In children, most of the subjects with SCH remain euthyroid over time, and therefore careful follow-up rather than treating them empirically was suggested (Moore, 1996; Radetti et al., 2006). It is commonly accepted that children with $\mathrm{TSH}$ above $10 \mathrm{mIU} / \mathrm{l}$ should be treated even if the $\mathrm{FT}_{4}$ is within a normal 
range while those with TSH between 4.5 and $10 \mathrm{mIU} / 1$ with thyroid autoantibodies should be followed up with repeated thyroid function tests but without treatment (Gopalakrishnan \& Marwaha, 2007). Still, the benefit of ${\mathrm{L}-\mathrm{T}_{4}}_{4}$ therapy has been questioned and some studies have shown no difference in metabolic parameters or neurocognitive function between treated and untreated subjects (Aijaz et al., 2006; Biondi \& Cooper, 2008). On the other hand, it has been shown that $\mathrm{L}_{-} \mathrm{T}_{4}$ therapy of patients with euthyroid AITD reduces both serological and cellular markers of autoimmune thyroiditis, indicating that $\mathrm{L}_{-} \mathrm{T}_{4}$ therapy might be useful in stopping disease progression (Padberg et al., 2001) and reducing thyroid volume in those patients with goiter (Svensson et al., 2006). Stable euthyroid hyperthyrotropinemia is a common condition that usually does not present with clinical symptoms or signs. Furthermore, biochemical parameters such as increased liver enzyme, hypercholesterolemia or elevated CPK are negative, indicating a euthyroid state. It is therefore recommended not to treat children without evidence of clinical hypothyroidism. However, those children with TSH above 10 $\mathrm{mIU} / \mathrm{l}$ or with a trend toward increasing TSH and decreasing $\mathrm{FT}_{4}$ over time might benefit from $\mathrm{L}-\mathrm{T}_{4}$ therapy. Side effects of $\mathrm{L}-\mathrm{T}_{4}$ therapy on the heart with such as resting tachycardia and on individuals' behavior, such as restlessness and sleep disturbances, should be considered in the clinical decisions for initiation of therapy. In euthyroid hyperthyrotropinemia caused by heterozygous loss-of-function mutation of TSHR, TSH levels tend to be stable over the years and therefore no therapy is indicated (Tenenbaum-Rakover, 2012). In newborns, a different approach should be taken since delay in therapy may result in permanent intellectual damage. In the case of TSH levels above $10 \mathrm{mIU} / \mathrm{l}$, early initiation of therapy should be considered, even if thyroid hormones are within the normal range. In view of the controversy that still exists around ${\mathrm{L}-\mathrm{T}_{4}}_{4}$ therapy in $\mathrm{SCH}$, it is recommended that the decision to initiate therapy be considered on an individual basis taking into account the benefits and possible side effects. In pregnant women and in newborns, initiation of therapy should be more urgent, whereas in other cases, sequential thyroid function tests along with clinical follow-up and further investigation, including laboratory, imaging and molecular analyses, might be a more reasonable approach prior to initiation of therapy.

\section{Conclusion}

The variable causes of SCH in children of different age groups were reviewed. The outcome of SCH in infancy and during childhood was shown to be dependent on etiology. Long-term follow-up is recommended since SCH may develop into overt hypothyroidism. Initiation of $\mathrm{L}-\mathrm{T}_{4}$ therapy in children, similar to adults, is still a matter of debate. In newborns, early initiation of therapy should be considered even if thyroid hormones are within the normal range to prevent possible late neurological sequels; in older children, on the other hand, it is recommended that the decision to initiate therapy be considered on an individual basis, taking into account its benefits and possible side effects. 


\section{Acknowledgements}

Thanks to Camille Vainstein for professional language editing.

\section{Author details}

Yardena Tenenbaum-Rakover*

Address all correspondence to: rakover_y@clalit.org.il

Ha'Emek Medical Center, Afula and The Ruth \& Rappoport Faculty of Medicine, Technion, Haifa, Israel

\section{References}

[1] Abalovich, M, Amino, N, Barbour, L. A, Cobin, R. H, De Groot, L. J, Glinoer, D, Mandel, S. J, \& Stagnaro-green, A. (2007). Management of thyroid dysfunction during pregnancy and postpartum: an Endocrine Society Clinical Practice Guideline. Journal of Clinical Endocrinology and Metabolism, Suppl.8, (August 2007), 0002-1972X, 92, S1S47.

[2] Alberti, L, Proverbio, M. C, Costagliola, S, Romoli, R, Boldrighini, B, Vigone, M. C, Weber, G, Chiumello, G, Beck-peccoz, P, \& Persani, L. (2002). Germline mutations of TSH receptor gene as cause of nonautoimmune subclinical hypothyroidism. Journal of Clinical Endocrinology and Metabolism, June 2002), 0002-1972X, 87(6), 2549-2555.

[3] Aijaz, N. J, Flaherty, E. M, Preston, T, Bracken, S. S, Lane, A. H, \& Wilson, T. A. Neurocognitive function in children with compensated hypothyroidism: lack of short term effects on or off thyroxin. BMJ Endociene disordes, March (2006). 1472-6823, 6(20), 2 .

[4] Batista, R. L, Toscanini, A. C, Glezer, A, Siqueira, M. G, Benabou, S, Fonoff, E. T, Tavares, W. M, \& Teixeira, M. J. Cunha Neto, M.B. ((2012). Approach to the patient with persistent hyperprolactinemia and negative sellar imaging. Journal of Clinical Endocrinology and Metabolism, July 2012), 0002-1972X, 97(7), 2211-2216.

[5] Biondi, B, \& Cooper, D. S. (2008). The clinical significance of subclinical thyroid dysfunction. Endocrine Reviews, February 2008), 0016-3769X, 29(1), 76-131.

[6] Breedveld, G. J, Van Dongen, J. W. F, Danesino, C, Guala, A, Percy, A. K, Dure, L. S, Harper, P, Lazarou, L. P, Van Der Linde, H, Joosse, M, \& Gruters, A. MacDonald, M.E.; de Vries, B.B.A.; Arts, W.F.M.; Oostra, B.A.; Krude, H. \& Heutink, P. ((2002). 
Mutations in TITF-1 are associated with benign hereditary chorea. Human Molecular Genetics, April 2002), 0964-6906, 11(8), 971-979.

[7] Brown, R. S, Bellisario, R. L, Botero, D, Fournier, L, Abrams, C. A, Cowger, M. L, David, R, Fort, P, \& Richman, R. A. (1996). Incidence of transient congenital hypothyroidism due to maternal thyrotropin receptor-blocking antibodies in over one million babies. Journal of Clinical Endocrinology and Metabolism, March 1996), 0002-1972X, 81(3), 1147-1151.

[8] Calaciura, F, Motta, R. M, Miscio, G, Fichera, G, Leonardi, D, Carta, A, Trischitta, V, Tassi, V, Sava, L, \& Vigneri, R. (2002). Subclinical hypothyroidism in early childhood: a frequent outcome of transient neonatal hyperthyrotropinemia. Journal of Clinical Endocrinology and Metabolism, July 2002), 0002-1972X, 87(7), 3209-3214.

[9] Chanoine, J. P, Boulvain, M, Bourdoux, P, Pardou, A, Van Thi, H. V, Ermans, A. M, \& Delange, F. (1988). Increased recall rate at screening for congenital hypothyroidism in breast fed infants born to iodine overloaded mothers. Archives of Disease in Childhood, October 1988), 0003-9888, 63(10), 1207-1210.

[10] Cheron, R. G, Kaplan, M. M, Larsen, P. R, Selenkow, H. A, \& Crigler, J. F. Jr. ((1981). Neonatal thyroid function after propylthiouracil therapy for maternal Graves' disease. New England Journal of Medicine, February 1981), 0028-4793, 304(9), 525-528.

[11] Chu, J. W, \& Crapo, L. M. (2001). The treatment of subclinical hypothyroidism is seldom necessary. Journal of Clinical Endocrinology and Metabolism, October 2001), 0002-1972X, 86(10), 4591-4599.

[12] Czernichow, P, Vandalem, J. L, \& Hennen, G. Transient neonatal hyperthyrotropinemia: a factitious syndrome due to the presence of heterophilic antibodies in the plasma of infants and their mothers. Journal of Clinical Endocrinology and Metabolism, August (1981). 0002-1972X, 53(2), 387-393.

[13] Daliva, A. L, \& Linder, B. DiMartino-Nardi, J. \& Saenger, P. ((2000). Three-year follow-up of borderline congenital hypothyroidism. Journal of Pediatrics, January 2000), 0022-3476, 136(1), 53-56.

[14] Damante, G. (1998). Thyroid defects due to Pax8 gene mutations. European Journal of Endocrinology, December 1998), 0804-4643, 139(6), 563-566.

[15] De Groot, L, Abalovich, M, Alexander, E. K, Amino, N, Barbour, L, Cobin, R. H, Eastman, C. J, Lazarus, J. H, Luton, D, Mandel, S. J, Mestman, J, Rovet, J, \& Sullivan, S. (2012). Management of Thyroid Dysfunction during Pregnancy and Postpartum: An Endocrine Society Clinical Practice Guideline. Journal of Clinical Endocrinology and Metabolism, August 2012), 0002-1972X, 97(8), 2543-2565.

[16] Delange, F, Dalhem, A, Bourdoux, P, Lagasse, R, Glinoer, D, Fisher, D. A, Walfish, P. G, \& Ermans, A. M. (1984). Increased risk of primary hypothyroidism in preterm infants. Journal of Pediatrics, September 1984), 0022-3476, 105(3), 462-469. 
[17] De Marco, G, Agretti, P, \& Montanelli, L. Di Cosmo, C.; Bagattini, B; De Servi, M.; Ferrarini, E.; Dimida, A.; Freitas Ferreira, A.C.; Molinaro, A.; Ceccarelli, C.; Brozzi, F.; Pinchera, A.; Vitti, P. \& Tonacchera, M. ((2011). Identification and functional analysis of novel dual oxidase 2 (DUOX2) mutations in children with congenital or subclinical hypothyroidism. Journal of Clinical Endocrinology and Metabolism, August 2011), 0002-1972X, 96(8), E1335-E1339.

[18] Demirbilek, H, Kandemir, N, Gonc, E. N, Ozon, A, Alikasifoglu, A, \& Yordam, N. (2007). Hashimoto's thyroiditis in children and adolescents: a retrospective study on clinical, epidemiological and laboratory properties of the disease. Journal of Pediatric Endocrinology and Metabolism, November 2007), 0033-4018X, 20(11), 1199-1205.

[19] De Roux, N, Misrahi, M, Brouner, R, Houang, M, Carel, J. C, \& Granier, M. Le Bouc, Y.; Ghinea, N.; Boumedienne, A.; Toublanc, J.E. \& Milgrom, E. ((1996). Four families with loss of function mutations of the thyrotropin receptor. Journal of Clinical Endocrinology and Metabolism, December 1996), 0002-1972X, 81(12), 4229-4235.

[20] Després, N, \& Grant, A. M. (1998). Antibody interference in thyroid assays: a potential for clinical misinformation. Clinical Chemistry, March 1998), 0009-9147, 44(3), 440-454.

[21] Devriendt, K, Vanhole, C, Matthijs, G, \& De Zegher, F. (1998). Deletion of thyroid transcription factor-1 gene in an infant with neonatal thyroid dysfunction and respiratory failure. (Letter) New England Journal of Medicine, April 1998), 0028-4793, 338(18), 1317-1318.

[22] De Vries, L, Bulvik, S, \& Phillip, M. (2009). Chronic autoimmune thyroiditis in children and adolescents: at presentation and during long-term follow-up. Archives of Disease in Childhood, January 2009), 0003-9888, 94(1), 33-37.

[23] Eliakim, A, Barzilai, M, Wolach, B, \& Nemet, D. (2006). Should we treat elevated thyroid stimulating hormone levels in obese children and adolescents? International Journal of Pediatric Obesity, April 2006), 1747-7166, 1(4), 217-221.

[24] Elmlinger, M. W, Kühnel, W, Lambrecht, H. G, \& Ranke, M. B. (2001). Reference intervals from birth to adulthood for serum thyroxine (T4), triiodothyronine (T3), free T3, free T4, thyroxine binding globulin (TBG) and thyrotropin (TSH). Clinical Chemistry and Laboratory Medicine, October 2001), 1437-4331, 39(10), 973-979.

[25] Fisher, D. A, \& Klein, A. H. (1981). Thyroid development and disorders of thyroid function in the newborn. New England Journal of Medicine, March 1981), 0028-4793, 304(12), 702-712.

[26] Fisher, D. A, \& Polk, D. H. (1989). Development of the thyroid. Baillieres Clinical Endocrinology and Metabolism, November 1989), 0095-0351X, 3(3), 627-657. 
[27] Fu, J, Jiang, Y, Liang, L, \& Zhu, H. (2005). Risk factors of primary thyroid dysfunction in early infants born to mothers with autoimmune thyroid disease. Acta Paediatrica, August 2005), 1651-2227, 94(8), 1043-1048.

[28] Gharib, H, Tuttle, R. M, Baskin, H. J, Fish, L. H, Singer, P. A, \& Mcdermott, M. T. (2004). Subclinical thyroid dysfunction: a joint statement on management from the American Association of Clinical Endocrinologists, the American Thyroid Association, and the Endocrine Society. Endocrine Practice, November-December 2004), 0153-0891X, 10(6), 497-501.

[29] Gopalakrishnan, S, \& Marwaha, R. K. (2007). Juvenile autoimmune thyroiditis. Journal of Pediatric Endocrinology and Metabolism, September 2007), 0033-4018X, 20(9), 961-970.

[30] Gopalakrishnan, S, Chugh, P. K, Chhillar, M, Ambardar, V. K, Sahoo, M, \& Sankar, R. (2008). Goitrous autoimmune thyroiditis in a pediatric population: a longitudinal study. Pediatrics, September 2008), 0031-4005, 122(3), e670-e674.

[31] Grandone, A, Santoro, N, Coppola, F, Calabrò, P, \& Perrone, L. Del Giudice, E.M. ((2010). Thyroid function derangement and childhood obesity: an Italian experience. BMC Endocrine Disorders, May 2010), 1472-6823, 10, 8.

[32] Grasberger, H, Vaxillaire, M, Pannain, S, Beck, J. C, Mimouni-bloch, A, Vatin, V, Vassart, G, Froguel, P, \& Refetoff, S. (2005). Identification of a locus for nongoitrous congenital hypothyroidism on chromosome 15q25.3-26.1. Human Genetics, December 2005), 0340-6717, 118(3-4), 348-355.

[33] Grüters, A, \& Krude, H. (2011). Detection and treatment of congenital hypothyroidism. Nature Reviews Endocrinology, October 2011), 1759-5029, 8(2), 104-113.

[34] Grüters, A, Allemand, 1, Heidemann, D, \& Schürnbrand, P. H. P. ((1983). Incidence of iodine contamination in neonatal transient hyperthyrotropinemia. European Journal of Pediatrics, September 1983), 0340-6199, 140(4), 299-300.

[35] Grüters, A, Delange, F, Giovannelli, G, Klett, M, Rochiccioli, P, Torresani, T, Grant, D, Hnikova, O, Maenpää, J, Rondanini, G. F, et al. (1993). Guidelines for neonatal screening programmes for congenital hypothyroidism. Working group on congenital hypothyroidism of the European Society for Paediatric Endocrinology. European Journal of Pediatrics, December 1993), 0340-6199, 152(12), 974-975.

[36] Grüters, A, Biebermann, H, \& Krude, H. (2003). Neonatal thyroid disorders. Hormone Research, Suppl.1, (January 2003), 0301-0163, 59, 24-29.

[37] Halsall, D. J, Fahie-wilson, M. N, Hall, S. K, Barker, P, Anderson, J, Gama, R, \& Chatterjee, V. K. (2006). Macro thyrotropin-IgG complex causes factitious increases in thyroid-stimulating hormone screening tests in a neonate and mother. Clinical Chemistry, 2006 October 2006), 0009-9147, 52(10), 1968-1969. 
[38] Halsall, D. J, English, E, \& Chatterjee, V. K. (2009). Interference from heterophilic antibodies in TSH assays. Annals of Clinical Biochemistry,July 2009), 0004-5632, 46(4), 345-346.

[39] Harris, K. B, \& Pass, K. A. (2007). Increase in congenital hypothyroidism in New York State and in the United States. Molecular Genetics and Metabolism, July 2007), Erratum in: Molecular Genetics and Metabolism, Vol.94, No.1, (May 2008), p. 140, 1096-7192, 91(3), 268-277.

[40] Hoste, C, Rigutto, S, Van Vliet, G, Miot, F, \& De Deken, X. (2010). Compound heterozygosity for a novel hemizygous missense mutation and a partial deletion affecting the catalytic core of the $\mathrm{H}_{2} \mathrm{O}_{2}$-generating enzyme DUOX2 associated with transient congenital hypothyroidism. Human Mutation,April 2010), 1098-1004, 31(4), E1304E1319.

[41] Hollowell, J. G, Staehling, N. W, Flanders, W. D, Hannon, W. H, Gunter, E. W, Spencer, C. A, \& Braverman, L. E. (2002). Serum TSH, T(4), and thyroid antibodies in the United States population (1988 to 1994): National Health and Nutrition Examination Survey (NHANES III). Journal of Clinical Endocrinology and Metabolism, February 2002), 0002-1972X, 87(2), 489-499.

[42] Huber, G, Staub, J. J, Meier, C, Mitrache, C, Guglielmetti, M, Huber, P, \& Braverman, L. E. (2002). Prospective study of the spontaneous course of subclinical hypothyroidism: prognostic value of thyrotropin, thyroid reserve, and thyroid antibodies. Journal of Clinical Endocrinology and Metabolism, July 2002), 0002-1972X, 87(7), 3221-3226.

[43] Hübner, U, Englisch, C, Werkmann, H, Butz, H, Georgs, T, Zabransky, S, \& Herrmann, W. (2002). Continuous age-dependent reference ranges for thyroid hormones in neonates, infants, children and adolescents established using the ADVIA Centaur Analyzer. Clinical Chemistry and Laboratory Medicine, October 2002), 1437-4331, 40(10), 1040-1047.

[44] Hume, R, Simpson, J, Delahunty, C, Van Toor, H, Wu, S. Y, Williams, F. L, \& Visser, T. J. (2004). Scottish Preterm Thyroid Group. Human fetal and cord serum thyroid hormones: developmental trends and interrelationships. Journal of Clinical Endocrinology and Metabolism, August 2004), 0002-1972X, 89(8), 4097-4103.

[45] Hunter, I, \& Greene, S. A. MacDonald, T.M. \& Morris, A.D. (2000). Prevalence and aetiology of hypothyroidism in the young. Archives of Disease in Childhood, September 2000), 0003-9888, 83(3), 207-210.

[46] Ismail, A. A, Walker, P. L, Barth, J. H, Lewandowski, K. C, Jones, R, \& Burr, W. A. (2002). Wrong biochemistry results: two case reports and observational study in 5310 patients on potentially misleading thyroid-stimulating hormone and gonadotropin immunoassay results. Clinical Chemistry, November 2002), 0009-9147, 48(11), 2023-2029.

[47] Jaruratanasirikul, S, Leethanaporn, K, Khuntigij, P, \& Sriplung, H. (2001). The clinical course of Hashimoto's thryoiditis in children and adolescents: 6 years longitudinal 
follow-up. Journal of Pediatric Endocrinology and Metabolism, February 2001), 0033-4018X, 14(2), 177-184.

[48] Jo, W, Ishizu, K, Fujieda, K, \& Tajima, T. (2010). Congenital hypothyroidism caused by a PAX8 gene mutation manifested as sodium/iodide symporter gene defect. Journal of Thyroid Research, Article ID 619013, 2042-0072, 2010(2010)

[49] Kapelari, K, Kirchlechner, C, Högler, W, Schweitzer, K, Virgolini, I, \& Moncayo, R. (2008). Pediatric reference intervals for thyroid hormone levels from birth to adulthood: a retrospective study. BMC Endocrine Disorders, November 2008), 1472-6823, 8, 15.

[50] Kaplan, I. V, \& Levinson, S. S. (1999). When is a heterophile antibody not a heterophile antibody? When it is an antibody against a specific immunogen Clinical Chemistry, May 1999), 0009-9147, 45(5), 616-618.

[51] Klett, M, \& Schönberg, D. (1981). Neonatal screening for hypothyroidism in the Federal Republic of Germany (author's transl)]. Deutsche Medizinische Wochenschrift, January 1981), 0012-0472, 106(1), 6-12.

[52] Koga, Y, Sano, H, Kikukawa, Y, Ishigouoka, T, \& Kawamura, M. (1995). Effect on neonatal thyroid function of povidone-iodine used on mothers during perinatal period. Journal of Obstetrics and Gynaecology, December 1995), 1701-2163, 21(6), 581-585.

[53] Köhler, B, Schnabel, D, Biebermann, H, \& Gruters, A. (1996). Transient congenital hypothyroidism and hyperthyrotropinemia: normal thyroid function and physical development at the ages of 6-14 years. Journal of Clinical Endocrinology and Metabolism, April 1996), 0002-1972X, 81(4), 1563-1567.

[54] Krude, H, Schutz, B, Biebermann, H, Von Moers, A, Schnabel, D, Neitzel, H, Tonnies, H, Weise, D, Lafferty, A, Schwarz, S, Defelice, M, Von Deimling, A, \& Van Landeghem, F. DiLauro, R., Gruters, A. ((2002). Choreoathetosis, hypothyroidism, and pulmonary alterations due to human NKX2-1 haploinsufficiency. Journal of Clinical Investigation, February 2002), 0021-9738, 109(4), 475-480.

[55] Leonardi, D, Polizzotti, N, Carta, A, Gelsomino, R, Sava, L, Vigneri, R, \& Calaciura, F. (2008). Longitudinal study of thyroid function in children with mild hyperthyrotropinemia at neonatal screening for congenital hypothyroidism. Journal of Clinical Endocrinology and Metabolism, July 2008), 0002-1972X, 93(7), 2679-2685.

[56] Liu, S. G, Zhang, S. S, Zhang, L. Q, Li, W. J, Zhang, A. Q, Lu, K. N, Wang, M. J, Yan, S. L, \& Ma, X. (2012). Screening of PAX8 mutations in Chinese patients with congenital hypothyroidism. Journal of Endocrinological Investigation, (January 2012), [Epub ahead of print], 0391-4097, 0391-4097.

[57] Loh, T. P, Kao, S. L, Halsall, D. J, Toh, S. A, Chan, E, Ho, S. C, Tai, E. S, \& Khoo, C. M. Macro-thyrotropin: a case report and review of literature. Journal of Clinical Endocrinology and Metabolism, June (2012). 0002-1972X, 97(6), 1823-1828. 
[58] Mantovani, G. (2011). Clinical review: Pseudohypoparathyroidism: diagnosis and treatment. Journal of Clinical Endocrinology and Metabolism, October 2011), 0002-1972X, 96(10), 3020-3030.

[59] Mantovani, G, Ballare, E, Giammona, E, Beck-peccoz, P, \& Spada, A. (2002). The gsalpha gene: predominant maternal origin of transcription in human thyroid gland and gonads. Journal of Clinical Endocrinology and Metabolism, October 2002), 0002-1972X, 87(10), 4736-4740.

[60] Marcocci, C, Vitti, P, Cetani, F, Catalano, F, Concetti, R, \& Pinchera, A. (1991). Thyroid ultrasonography helps to identify patients with diffuse lymphocytic thyroiditis who are prone to develop hypothyroidism. Journal of Clinical Endocrinolology $\mathcal{E} M e^{-}$ tabolism, January 1991), 0002-1972X, 72(1), 209-213.

[61] Maruo, Y, Takahashi, H, Soeda, I, Nishikura, N, Matsui, K, Ota, Y, Mimura, Y, Mori, A, Sato, H, \& Takeuchi, Y. (2008). Transient congenital hypothyroidism caused by biallelic mutations of the dual oxidase 2 gene in Japanese patients detected by a neonatal screening program. Journal of Clinical Endocrinology and Metabolism, November 2008), 0002-1972X, 93(11), 4261-4267.

[62] Marwaha, R. K, Tandon, N, Kanwar, R, Ganie, M. A, Bhattacharya, V, Reddy, D. H, Gopalakrishnan, S, Aggarwal, R, Grewal, K, Ganguly, S. K, \& Mani, K. (2008). Evaluation of the role of ultrasonography in diagnosis of autoimmune thyroiditis in goitrous children. Indian Pediatrics, April 2008), 0019-6061, 45(4), 279-284.

[63] Matsuura, N, \& Konishi, J. (1990). Transient hypothyroidism in infants born to mothers with chronic thyroiditis-a nationwide study of twenty-three cases. The Transient Hypothyroidism Study Group. Endocrinology Japan, June 1990), Erratum in: Endocrinology Japan, Vol.37, No.5, (October 1990) p. 767, 0013-7219, 37(3), 369-379.

[64] Matsuura, N, Yamada, Y, Nohara, Y, Konishi, J, Kasagi, K, Endo, K, Kojima, H, \& Wataya, K. (1980). Familial neonatal transient hypothyroidism due to maternal TSHbinding inhibitor immunoglobulins. New England Journal of Medicine, September 1980), 0028-4793, 303(13), 738-741.

[65] Mendoza, H, Connacher, A, \& Srivastava, R. (2009). Unexplained high thyroid stimulating hormone: a "BIG" problem. BMJ Case Reports, pii: bcr01.2009.1474, Epub Apr 14 2009, 0175-7790X, 1757-790.

[66] Miki, K, Nose, O, Miyai, K, Yabuuchi, H, \& Harada, T. (1989). Transient infantile hyperthyrotrophinaemia. Archives of Disease in Childhood, August 1989), 0003-9888, 64(8), 1177-1182.

[67] Moore, D. C. (1996). Natural course of'subclinical' hypothyroidism in childhood and adolescence. Archives of Pediatrics and Adolescent Medicine, March 1996), 1072-4710, 150(3), 293-297.

[68] Moreno, J. C, Bikker, H, Kempers, M. J, Van Trotsenburg, A. S, Baas, F, De Vijlder, J. J, Vulsma, T, \& Ris-stalpers, C. (2002). Inactivating mutations in the gene for thyroid 
oxidase 2 (THOX2) and congenital hypothyroidism. New England Journal of Medicine, July 2002), 0028-4793, 347(2), 95-102.

[69] Narumi, S, Yoshida, A, Muroya, K, Asakura, Y, Adachi, M, Fukuzawa, R, Kameyama, K, \& Hasegawa, T. (2011). PAX8 mutation disturbing thyroid follicular growth: a case report. Journal of Clinical Endocrinology and Metabolism, December 2011), 0002-1972X, 96(12), E2039-E2044.

[70] Narumi, S, Araki, S, Hori, N, Muroya, K, Yamamoto, Y, Asakura, Y, Adachi, M, \& Hasegawa, T. (2012). Functional characterization of four novel PAX8 mutations causing congenital hypothyroidism: new evidence for haploinsufficiency as a disease mechanism. European Journal of Endocrinology, (Aug 2012), [Epub ahead of print], 0804-4643, 0804-4643.

[71] Newman, J. D, Bergman, P. B, Doery, J. C, \& Balazs, N. D. (2006). Factitious increase in thyrotropin in a neonate caused by a maternally transmitted interfering substance. Clinical Chemistry, March 2006), 0009-9147, 52(3), 541-542.

[72] Nishiyama, S, Mikeda, T, Okada, T, Nakamura, K, Kotani, T, \& Hishinuma, A. (2004). Transient hypothyroidism or persistent hyperthyrotropinemia in neonates born to mothers with excessive iodine intake. Thyroid, December 2004), 1050-7256, 14(12), 1077-1083.

[73] Ogilvy-stuart, A. L. (2002). Neonatal thyroid disorders. Archives of Disease in Childhood-Fetal and Neonatal Edition, November 2002), 1359-2998, 87(3), F165-F171.

[74] Ohye, H, Fukata, S, Hishinuma, A, Kudo, T, Nishihara, E, Ito, M, Kubota, S, Amino, N, Ieiri, T, Kuma, K, \& Miyauchi, A. (2008). A novel homozygous missense mutation of the dual oxidase 2 (DUOX2) gene in an adult patient with large goiter. Thyroid, May 2008), 1050-7256, 18(5), 561-566.

[75] Özen, S, Berk, Ö, Simsek, D. G, \& Darcan, S. (2011). Clinical course of Hashimoto's thyroiditis and effects of levothyroxine therapy on the clinical course of the disease in children and adolescents. Journal of Clinical Research in Pediatric Endocrinology, April 2011), 1308-5727, 3(4), 192-197.

[76] Padberg, S, Heller, K, Usadel, K. H, \& Schumm-draeger, P. M. (2001). One-year prophylactic treatment of euthyroid Hashimoto's thyroiditis patients with levothyroxine: is there a benefit? Thyroid, March 2001), 1050-7256, 11(3), 249-255.

[77] Papendieck, P, Chiesa, A, Prieto, L, \& Gruñeiro-papendieck, L. (2009). Thyroid disorders of neonates born to mothers with Graves' disease. Journal of Pediatric Endocrinology and Metabolism, June 2009), 0033-4018X, 22(6), 547-553.

[78] Park, S. M, \& Chatterjee, V. K. (2005). Genetics of congenital hypothyroidism. Journal of Medical Genetics, May 2005), 0022-2593, 42(5), 379-389. 
[79] Pedersen, O. M, Aardal, N. P, Larssen, T. B, Varhaug, J. E, Myking, O, \& Vik-mo, H. (2000). The value of ultrasonography in predicting autoimmune thyroid disease. Thyroid, March 2000), 1050-7256, 10(3), 251-259.

[80] Pohlenz, J, Dumitrescu, A, Zundel, D, Martine, U, Schonberger, W, Koo, E, Weiss, R. E, Cohen, R. N, Kimura, S, \& Refetoff, S. (2002). Partial deficiency of thyroid transcription factor 1 produces predominantly neurological defects in humans and mice. Journal of Clinical Investigation, No., (MONTH 2002), 0021-9738, 109, 469-473.

[81] Raber, W, Gessl, A, Nowotny, P, \& Vierhapper, H. (2002). Thyroid ultrasound versus antithyroid peroxidase antibody determination: a cohort study of four hundred fiftyone subjects. Thyroid, August 2002), 1050-7256, 12(8), 725-731.

[82] Radetti, G, Gottardi, E, Bona, G, Corrias, A, Salardi, S, \& Loche, S. Study Group for Thyroid Diseases of the Italian Society for Pediatric Endocrinology and Diabetes (SIEDP/ISPED)((2006). The natural history of euthyroid Hashimoto's thyroiditis in children. Journal of Pediatrics, December 2006), 0022-3476, 149(6), 827-832.

[83] Rago, T, Chiovato, L, Grasso, L, Pinchera, A, \& Vitti, P. (2001). Thyroid ultrasonography as a tool for detecting thyroid autoimmune diseases and predicting thyroid dysfunction in apparently healthy subjects. Journal of Endocrinology Investigation, November 2001), 0391-4097, 24(10), 763-769.

[84] Rakover, Y, \& Adar, H. (1989). Thyroid function disturbances in an infant following maternal topical use of polydine]. Harefuah May 1989), 0017-7768, 116(10), 527-529.

[85] Rakover, Y, Sadeh, O, Sobel, E, Shneyour, A, \& Kraiem, Z. (1990). A case of transient hypothyroidism: sequential serum measurements of autoantibodies inhibiting thyrotropin-stimulated thyroid cAMP production in a neonate. Acta Endocrinologica (Copenh), July 1990), 0001-5598, 123(1), 118-122.

[86] Rakover, Y, Weiner, E, Mosh, N, \& Shalev, E. (1999). Fetal pituitary negative feedback at early gestational age. Clinical Endocrinology, June 1999), 0300-0664, 50(6), 809-814.

[87] Rallison, M. L, Dobyns, B. M, Meikle, A. W, Bishop, M, Lyon, J. L, \& Stevens, W. (1991). Natural history of thyroid abnormalities: prevalence, incidence, and regression of thyroid diseases in adolescents and young adults. The American Journal of Medicine, October 1991), 0002-9343, 91(4), 363-370.

[88] Refetoff, S. (2003). Resistance to thyrotropin. Journal of Endocrinological Investigation, August 2003), 0391-4097, 26(8), 770-779.

[89] Reinehr, T. (2011). Thyroid function in the nutritionally obese child and adolescent. Current Opinion in Pediatrics, August 2011), 1040-8703, 23(4), 415-420.

[90] Reinehr, T, De Sousa, G, \& Andler, W. (2006). Hyperthyrotropinemia in obese children is reversible after weight loss and is not related to lipids. Journal of Clinical Endocrinology and Metabolism, August 2006), 0002-1972X, 91(8), 3088-3091. 
[91] Rix, M, Laurberg, P, Porzig, C, \& Kristensen, S. R. (2011). Elevated thyroid-stimulating hormone level in a euthyroid neonate caused by macro thyrotropin-IgG complex. Acta Paediatrica, September 2011), 1651-2227, 100(9), e135-e137.

[92] Ross, H. A, Menheere, P. P. C. A, Thomas, C. M. G, Mudde, A. H, Kouwenberg, M, \& Wolffenbuttel, B. H. R. (2008). Interference from heterophilic antibodies in seven current TSH assays. Annals of Clinical Biochemistry, November 2008), 0004-5632, 45(6), 616.

[93] Sakai, H, Fukuda, G, Suzuki, N, Watanabe, C, \& Odawara, M. (2009). Falsely elevated thyroid-stimulating hormone (TSH) level due to macro-TSH. Endocrine Journal, April 2009), 0918-8959, 56(3), 435-440.

[94] Sakka, S. D, Malamitsi-puchner, A, Loutradis, D, Chrousos, G. P, \& Kanaka-gantenbein, C. (2009). Euthyroid hyperthyrotropinemia in children born after in vitro fertilization. Journal of Clinical Endocrinology and Metabolism, April 2009), 0002-1972X, 94(4), 1338-1341.

[95] Samuels, M. H, Schuff, K. G, Carlson, N. E, Carello, P, \& Janowsky, J. S. (2008). Health status, mood, and cognition in experimentally induced subclinical thyrotoxicosis. Journal of Clinical Endocrinology and Metabolism, May 2008), 0002-1972X, 93(5), 1730-1736.

[96] Sava, L, Delange, F, Belfiore, A, Purrello, F, \& Vigneri, R. (1984). Transient impairment of thyroid function in newborn from an area of endemic goiter. Journal of Clinical Endocrinology and Metabolism, July 1984), 0002-1972X, 59(1), 90-95.

[97] Shalitin, S, Yackobovitch-gavan, M, \& Phillip, M. (2009). Prevalence of thyroid dysfunction in obese children and adolescents before and after weight reduction and its relation to other metabolic parameters. Hormone Research, March 2009), 0301-0163, 71(3), 155-161.

[98] Skarpa, V, Kappaousta, E, Tertipi, A, Anyfandakis, K, Vakaki, M, Dolianiti, M, Fotinou, A, \& Papathanasiou, A. (2011). Epidemiological characteristics of children with autoimmune thyroid disease. Hormones (Athens), July-September 2011), 1109-3099, 10(3), 207-214.

[99] Soldin, O. P, Jang, M, Guo, T, \& Soldin, S. J. (2009). Pediatric reference intervals for free thyroxine and free triiodothyronine. Thyroid, July 2009), 1050-7256, 19(7), 699-702.

[100] Strich, D, Edri, S, \& Gillis, D. (2012). Current normal values for TSH and FT3 in children are too low: evidence from over 11,000 samples. Journal of Pediatric Endocrinology and Metabolism, March 2012), 0033-4018X, 25(3-4), 245-248.

[101] Surks, M. I, Ortiz, E, Daniels, G. H, Sawin, C. T, Col, N. F, Cobin, R. H, Franklyn, J. A, Hershman, J. M, Burman, K. D, Denke, M. A, Gorman, C, Cooper, R. S, \& Weissman, N. J. (2004). Subclinical thyroid disease: scientific review and guidelines for diagnosis 
and management. Journal of the American Medical Association, January 2004), 0098-7484, 291(2), 228-238.

[102] Surks, M. I, Goswami, G, \& Daniels, G. H. (2005). The thyrotropin reference range should remain unchanged. Journal of Clinical Endocrinology and Metabolism, September 2005), 0002-1972X, 90(9), 5489-5496.

[103] Svensson, J, Ericsson, U. B, Nilsson, P, Olsson, C, Jonsson, B, Lindberg, B, \& Ivarsson, S. A. (2006). Levothyroxine treatment reduces thyroid size in children and adolescents with chronic autoimmune thyroiditis. Journal of Clinical Endocrinology and Metabolism, May 2006), 0002-1972X, 91(5), 1729-1734.

[104] Tenenbaum-rakover, Y. (2012). The clinical spectrum of thyrotropin receptor gene (tshr) mutations. In: Hypothyroidism- Influences and Treatments, D. Springer, (Ed.), InTech, 978-9-53510-021-8Available from: http://www.intechopen.com/articles/show/ title/the-clinical-spectrum-of-tsh-receptor-tshr-mutations

[105] Tenenbaum-rakover, Y, Grasberger, H, Mamanasiri, S, Ringkananont, U, Montanelli, L, Barkoff, M. S, Dahood, A. M, \& Refetoff, S. (2009). Loss-of-function mutations in the thyrotropin receptor gene as a major determinant of hyperthyrotropinemia in a consanguineous community. Journal of Clinical Endocrinology and Metabolism, May 2009), 0002-1972X, 94(5), 1706-1712.

[106] Thorpe-beeston, J. G, Nicolaides, K. H, Felton, C. V, Butler, J, \& Mcgregor, A. M. (1991). Maturation of the secretion of thyroid hormone and thyroid-stimulating hormone in the fetus. New England Journal of Medicine, February 1991), 0028-4793, 324(8), 532-536.

[107] Vanderpump, M. P, \& Tunbridge, W. M. (2002). Epidemiology and prevention of clinical and subclinical hypothyroidism. Thyroid, October 2002), 1050-7256, 12(10), 839-847.

[108] Vilain, C, Rydlewski, C, Duprez, L, Heinrichs, C, Abramowicz, M, Malvaux, P, Renneboog, B, Parma, J, Costagliola, S, \& Vassart, G. (2001). Autosomal dominant transmission of congenital thyroid hypoplasia due to loss-of-function mutation of PAX8. Journal of Clinical Endocrinology and Metabolism, January 2001), 0002-1972X, 86(1), 234-238.

[109] Wada, K, Kazukawa, I, Someya, T, Watanabe, T, Minamitani, K, Minagawa, M, Wataki, K, Nishioka, T, \& Yasuda, T. (2000). Maternal hypothyroidism in autoimmune thyroiditis and the prognosis of infants. Endocrine Journal, Suppl., (March 2000), 0918-8959, 47, S133-S135.

[110] Wartofsky, L, \& Dickey, R. A. (2005). The evidence for a narrower thyrotropin reference range is compelling. Journal of Clinical Endocrinology and Metabolism, September 2005), 0002-1972X, 90(9), 5483-5488. 
[111] Raber, W, Gessl, A, Nowotny, P, \& Vierhapper, H. (2002). Thyroid ultrasound versus antithyroid peroxidase antibody determination: a cohort study of four hundred fiftyone subjects. Thyroid, Augost 2002), 1050-7256, 12(8), 725-531.

[112] Xie, J, Pannain, S, Pohlenz, J, Weiss, R. E, Moltz, K, Morlot, M, Asteria, C, Persani, L, Beck-peccoz, P, Parma, J, Vassart, G, \& Refetoff, S. (1997). Resistance to thyrotropin (TSH) in three families is not associated with mutations in the TSH receptor or TSH. Journal of Clinical Endocrinology and Metabolism, December 1997), 0002-1972X, 82(12), 3933-3940.

[113] Zakarija, M, Mckenzie, J. M, \& Eidson, M. S. (1990). Transient neonatal hypothyroidism: characterization of maternal antibodies to the thyrotropin receptor. Journal of Clinical Endocrinology and Metabolism, May 1990), 0002-1972X, 70(5), 1239-1246.

[114] Zung, A, Tenenbaum-rakover, Y, Barkan, S, Hanukoglu, A, Hershkovitz, E, Pinhashamiel, O, Bistritzer, T, \& Zadik, Z. (2010). Neonatal hyperthyrotropinemia: population characteristics, diagnosis, management and outcome after cessation of therapy. Clinical Endocrinology, February 2010), 0300-0664, 72(2), 264-271.

[115] Zurakowski, D. Di Canzio, J. \& Majzoub, JA. ((1999). Pediatric reference intervals for serum thyroxine, triiodothyronine, thyrotropin, and free thyroxine. Clinical Chemistry, July 1999), 0009-9147, 45(7), 1087-1091. 